\title{
Basement relief estimative of the Parnaíba basin's west border through 2D gravity modelling
}

\author{
Raphael Di Carlo Silva dos Santos ${ }^{1}$, Giorgio Arlan da Silva Picanço¹, Raimundo Nonato Colares Carneiro¹, Karina Palheta \\ Gomes $^{2}$ \\ 1 Universidade Federal do Oeste do Pará \\ 2 Universidade Federal do Pará
}

\section{Copyright 2016, SBGf - Sociedade Brasileira de Geofísica}

Este texto foi preparado para a apresentação no VII Simpósio Brasileiro de Geofísica, Ouro Preto, 25 a 27 de outubro de 2016. Seu conteúdo foi revisado pelo Comitê Técnico do VII SimBGt, mas não necessariamente representa a opinião da SBGf ou de seus associados. É proibida a reprodução total ou parcial deste material para propósitos comerciais sem prévia autorização da SBGf.

\begin{abstract}
We present a gravity interpretation of the west border of the Parnaíba basin's basement relief. The residual Bouguer anomaly produced by the basin was estimated through the information of the Moho depth and spectral analysis. We interpreted six profiles across the basin strike through 2D modelling. We obtained depths less than $2 \mathrm{~km}$ indicating a shallow embasament compared to the main depocenter and the northeast border of the basin.
\end{abstract}

\section{Introduction}

The Parnaíba basin is localized in the brazilian northeast occupying an area of approximately $600,000 \mathrm{~km}^{2}$ inside the states of Maranhão, Piauí, Ceará, Tocantins and Pará (fig.1). Its extension is of $1000 \mathrm{~km}$ across NW-SE and $800 \mathrm{~km}$ across NE-SW direction with a maximum depocenter reaching $3.5 \mathrm{~km}$ in the central portion (VAZ et al., 2007). It is classified as an intracratonic basin according to Klemme (1980).

Many geophysical methods has been applied to interpret its tectonic structures and to map the basemente relief like the seismic methods (e.g. PINHEIRO, 2011; CARVALHO, 2012), EM methods (ABREU, 2002) and gravity method (BRANCO et al., 2015).

In this work we propose an interpretation of 6 gravity profiles of the west border of the Parnaíba basin. In order to pre-process the gravity data we use sequentially: the krigging method for data interpolation, and the a priori information of the depth of the Moho descontinuity through de GOCCE project (REGUZONI \& SAMPIETRO, 2015; REGUZONI et al., 2013) - for a first regionalresidual filtering. After we get the filtered data we applied a second regional-residual filtering using the spectral analysis (SPECTOR \& GRANT, 1970). Afterwards, when we get the final residual anomaly, we sampled the gravity profiles. We modeled the basement relief of these profiles which generated depths less than $2 \mathrm{~km}$, showing a shallow basement in comparison with the main depocenter and the northeast portion.

\section{Geology of the Parnaíba Basin}

The Parnaíba Basin has developed under a continental basement during the Stage of Stabilization of the South American Platform (VAZ et al., op.cit.). Its basement is consisted of metamorphic, igneous and sedimentary rocks, which ages range from Archean to Ordovician. The origin of the basin is probably connected to the deformation and fini- and post-orogenic thermical events from the Brasiliano Cycle, otherwise the origin of its depocenter is linked to the graben-like structures. The basement contains the Riachão formation, composed of graywacke, silts, red shales and ignimbrites, and the Jaibaras Group, composed of fluvial, alluvial and lacustrine deposits (VAZ et al., op.cit.). All the west border of the basement is composed by the Araguaia-Tocantins belt from Proterozoic (ABREU, op. cit.).

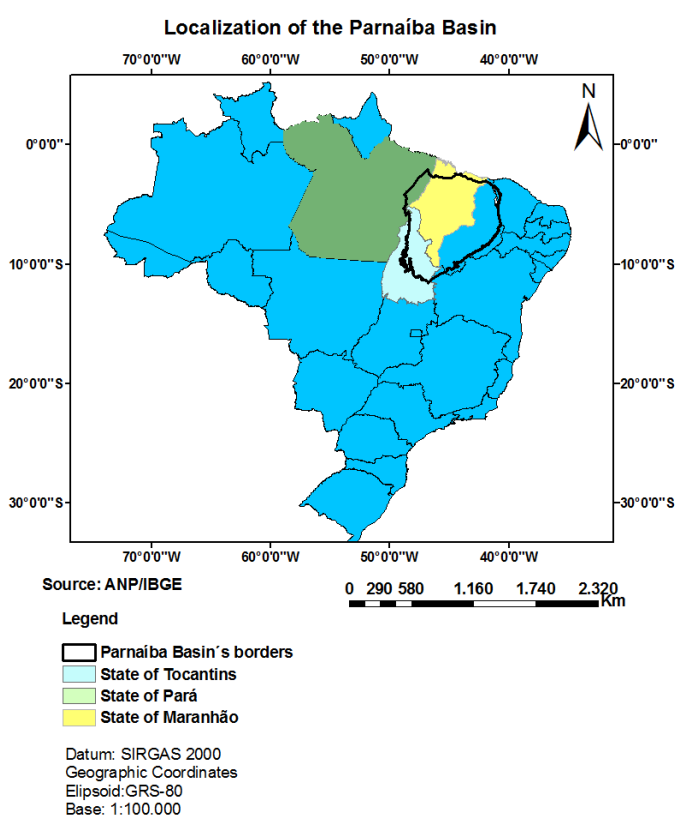

Figure 1 - Localization of the Parnaíba Basin.

\section{Localization of the gravity data}

It was acquired 441 stations localized approximately between the coordinates $\left(48.9^{\circ} \mathrm{W}, 5.271^{\circ} \mathrm{S}\right)$ and 
$\left(42^{\circ} \mathrm{W}, 5.271^{\circ} \mathrm{W}\right)$ reaching the states of Pará, Tocantins and Maranhão (fig.2). We used the krigging method with the semivariogram modelling for the data interpolation. The data are shown in the figure 3.

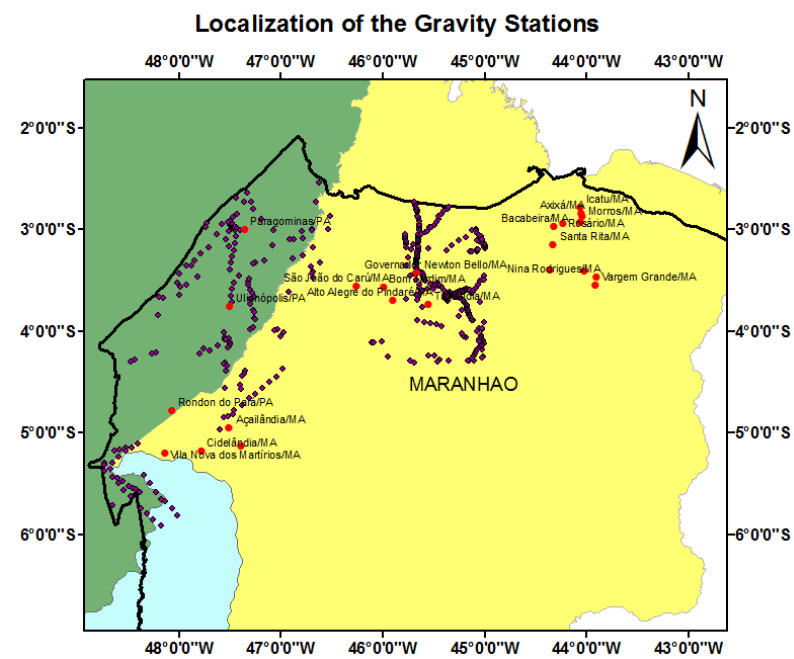

Source: Bureau Gravimétrique International/IBGE \begin{tabular}{llllll}
0 & 30 & 60 & 120 & 180 & 240 \\
\hline
\end{tabular} Legend

- Cities

- Gravity Stations

$\square$ Parnaíba Basin's borders State of Tocantins State of Pará State of Maranhão

Datum: SIRGAS 2000 Geographic Coordinates Elipsoid:GRS-80 Base: 1:100.000

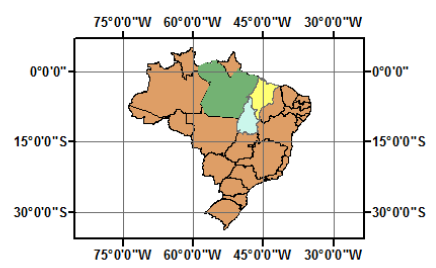

Figure 2 - Localization of the gravity data. Source: Drewes et al. (2012).

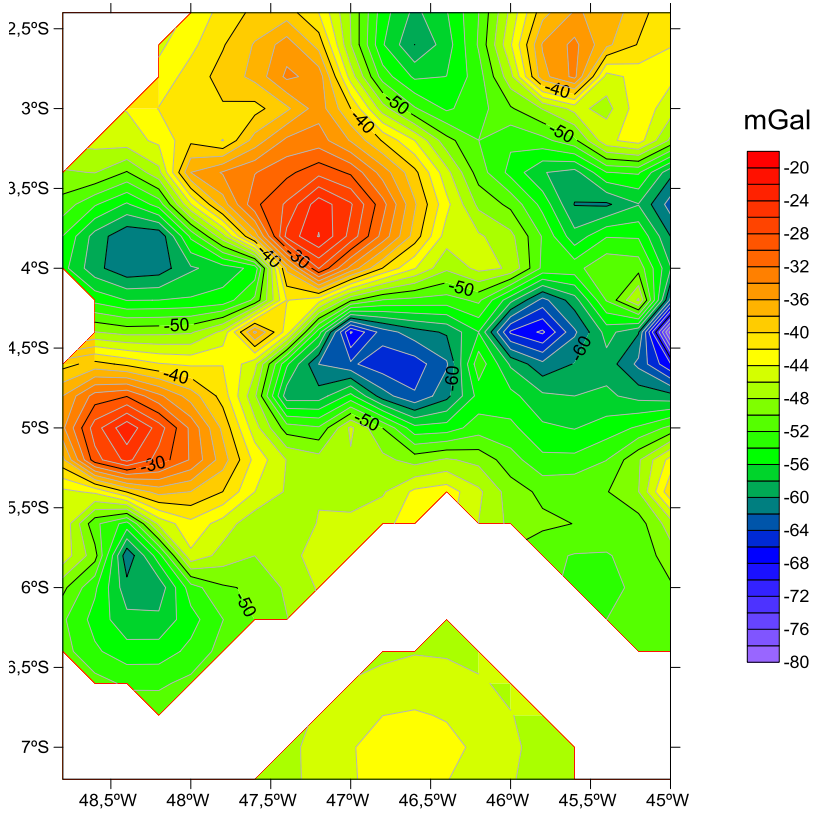

Figure 3 - Interpolated gravity anomaly through the krigging method.

\section{Regional-Residual Filtering}

The regional-residual filtering was performed in two steps: the first one is for cancelling the effect of the Moho descontinuity and the second one is for cancelling the effects of sources from inside the sedimentary package.

We performed the first step through the a priori information of the depths of Moho from the GEMMA (GOCE Exploitation for Moho Modeling and Application) project which maps the depth of the Moho around the world. This mapping is obtained from the satellite gravity project GOCE (DRINKWATER et. Al., 2003). The depth model is parameterized in therms of spherical harmonics using grids with resolution of $0.5^{\circ} \times 0.5^{\circ}$, moreover the data misfit is based on the Monte Carlo method (REGUZONI \& SAMPIETRO, 2015). For this filtering we used a model for Moho with parallel layers with constant density.

We used an average Moho's depth of $38 \mathrm{~km}$ for the survey area. Furthermore we performed an upward continuation of $38 \mathrm{~km}$ (fig. 4) and subtracted the original interpolated anomaly from the upwarded anomaly. This subtraction resulted in the figure 5 .

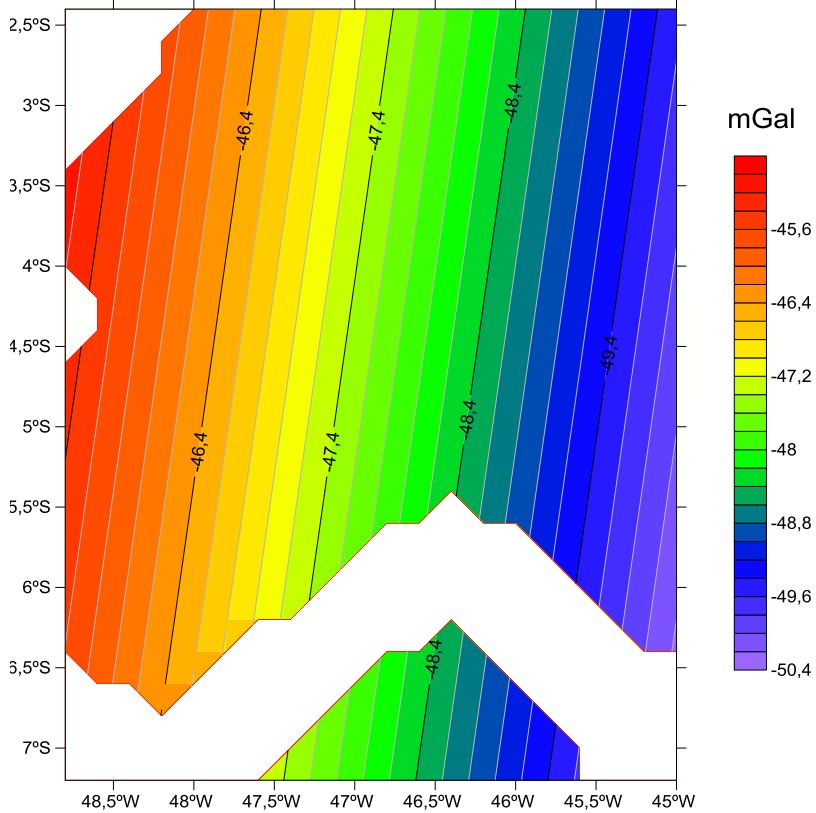

Figure 4 - Anomaly after the upward continuation. 


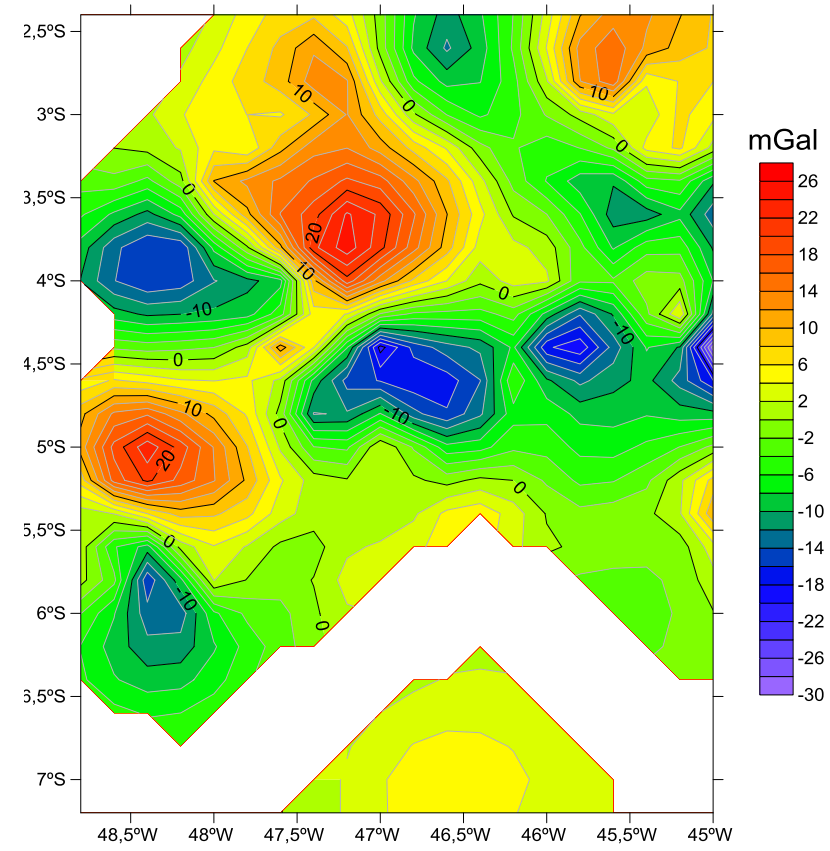

Figure 5 - First residual anomaly.

After we have the first residual anomaly, we performed the seconde step. It consists in split two effects, one from the basement-sediments interface and one from internal sources of the basin. In order to perform this splitting we used the spectral analysis method (SPECTOR \& GRANT, 1970). We applied a bandpass filter to separate the tendentiousness of the logarithmitic curve which split the power spectrum created by shallow and deep sources (fig.6). Once we separate the sources, we get the final residual gravity map due to the basement-sediments interface only (fig. 7).

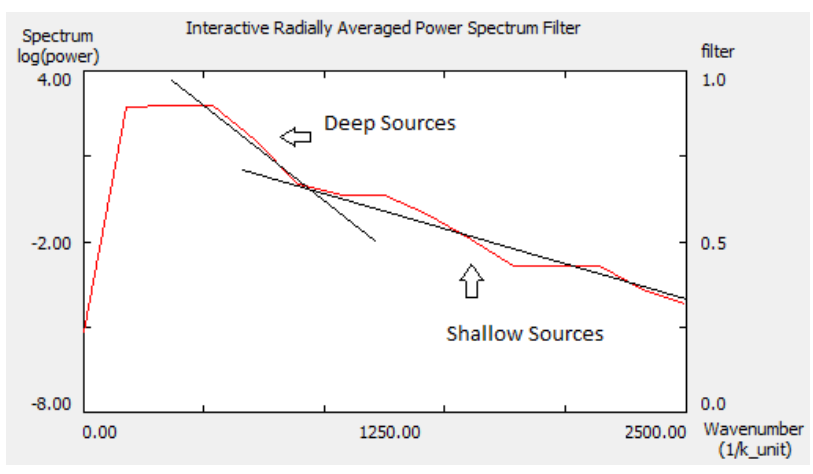

Figura 6 - Power spectrum which splits the regional and residual components of the field.

\section{Modelling and interpretation}

We obtained 6 profiles from the gravity residual map (fig.7). To modelate them we used the software GMULTI and a constant density contrast of $-0,25 \mathrm{~g} / \mathrm{cm}^{3}$ based on the gravity modelling of the northeast border of the
Parnaíba basin (BRANCO et al., 2015). All the profiles were sampled such that they could contain the maximum number of stations that were not contaminated from the interpolation.

The profile AA' contains 9 stations and a maximum depocenter depth of $1.65 \mathrm{~km}$ (fig.8). The profile BB' contains 9 stations and a maximum depth of $1.23 \mathrm{~km}$ (fig.9). The profile CC' contains 9 stations and a maximum depth of $1.58 \mathrm{~km}$ (fig.10). The profile DD' contains 8 stations and a maximum depth of $680 \mathrm{~m}$ (fig.11). The profile EE' contains 8 stations and a maximum depth of $300 \mathrm{~m}$ (fig.12). And the profile FF' contains 8 stations and a maximum depth of $290 \mathrm{~m}$ (fig.13).

We noticed a great variation of maximum depth of each profile. We may associate it to the possible tectonicsedimentary drifts of Araguaia-Tocantins belt.

In relation to the northeast border, with depths reaching from $300 \mathrm{~m}$ to $2 \mathrm{~km}$ or plus (ABREU, 2002; BRANCO et al., 2015), the west border showed shallow depths indicating a shallow zone.

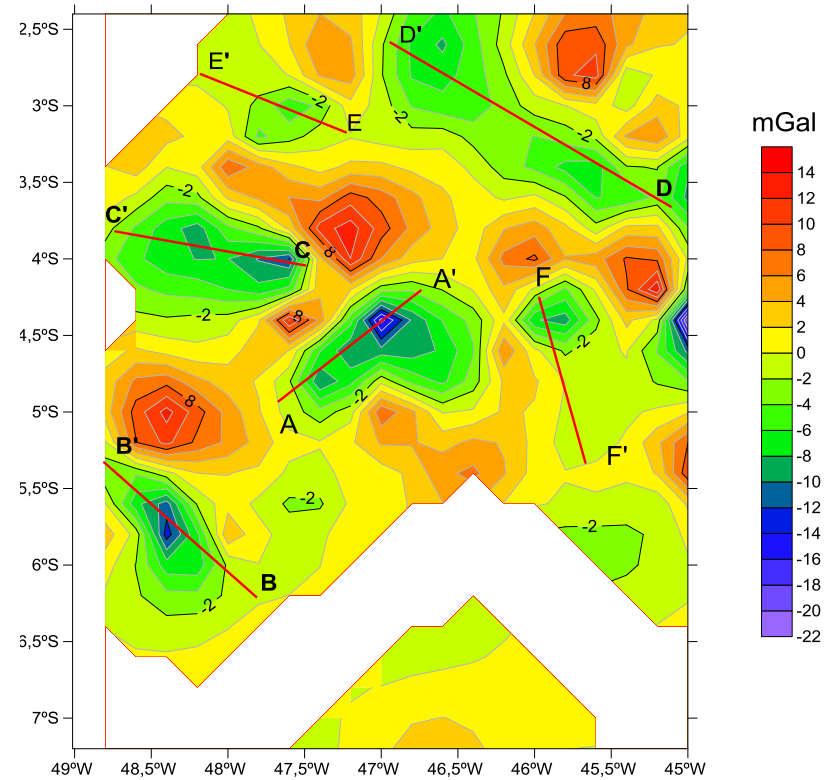

Figure 7 - Second residual anomaly and localization of the profiles. 


\section{Conclusions}

We presented in this work the interpretation of six gravity profiles of the Parnaíba basin.

The residual anomaly generated due to the basementsediments interface was obtained using two different methodologies for regional-residual filtering: the first one using the a priori information of the Moho's depth and the second one using the spectral analysis. We produced estimates of the depths shallow than $2 \mathrm{~km}$ indicating a shallower portion in comparison with the northeast border.

Future analysis for the interpretation of Parnaíba basin basement relief might include inversion with total variation constraint, which allows to iluminate high-angle faults, and 3D depth estimate.

\section{Acknowledgments}

The authors thank to the International Gravimetric Bureau for sharing the gravity data and Prof. João Batista (UFPA) for sharing the license of the GMULTI software.

\section{References}

Abreu, P.M. 2002. Estudos geofísicos (magnetotelúrico e eletromagnético transiente) da porção leste da bacia do Parnaíba: contribuição ao conhecimento hidrogeológico. Dissertação de Mestrado.Rio de Janeiro. Observatório Nacional. 130p.

Branco, R.M.G.C.; Junior, N.C.P.; Aguiar, R.B.; Martins, J.A.; Silva, N.C.V. 2015. Gravimetria da borda nordeste da bacia do Parnaíba. 14th Congress of International Congress of the Brazilian Geophysical Society Annals. Rio de Janeiro.

Carvalho, B.R.; Oguro, A.; Ribeiro, R.B. $2012 . \quad$ Uso de AVO para identificação de selos: um estudo de caso da bacia do Parnaíba. Anais do V Simpósio Brasileiro de Geofísica. Salvador.

Drewes, H.; Hornik, H.; Ádám, J.; Rósza, S. 2012. "The International Gravimetric Bureau". In: IAG Geodesist's Handbook, 2012 - Journal of Geodesy, V 86, N 10, Oct. 2012, Springer.

Drinkwater, M.R.; Flobergahen, R.; Haagmans, D.; Muzi, A.; Pospecu. GOCE: ESA's frist Earth Explorer Core Mission. Neverland: Kluwer Academic Publishers, 2003 . p. 414-432 (Space Sciences Series of ISSI, v. 18).

Klemme, H. D. 1980. Petroleum basins - classification and characteristic. J. petrol. Geol., 3, p. 187-207.

Pinheiro, A.G. 2011. Interpretação sísmica 2D e modelagem geológica 2,5D da bacia do Parnaíba.Trabalho de Conclusão de Curso. Belém. Universidade Federal do Pará. 87p.

Reguzzoni, M.; Sampietro, D . 2015. GEMMA: An Earth crustal model based on GOCE satellite data. International
Journal of Applied Earth Observation and Geoinformation, Vol. 35, Part A, pp. 31-43.

Sampietro, D.; Reguzzoni, M; Negretti, M .2013. The GEMMA crustal model: first validation and data distribution. In: Proceedings of the ESA Living Planet Symposium. Edinburgh (UK), ESA SP-722.

Vaz, P.T.; Rezende, N.G.A.M.; Filho, J.R.W.; Travassos, W.A.S.; 2007. Bacia do Parnaíba. Boletim de Geociências da Petrobras. Rio de Janeiro, vol. 15, n.2, p.253-263. 
(a)

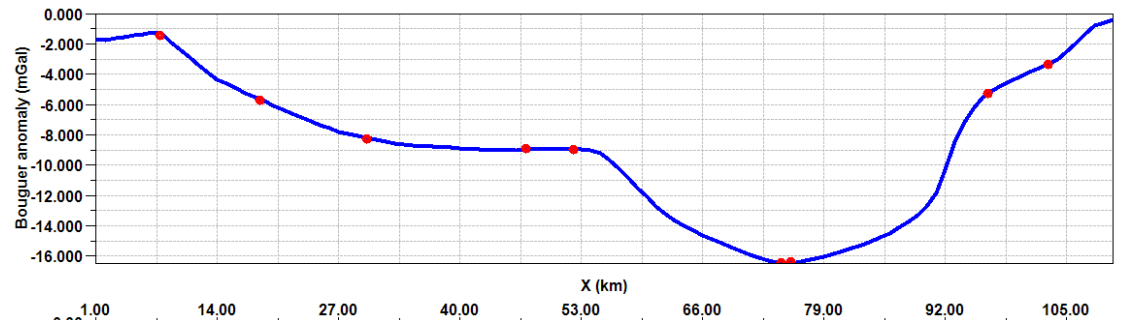

(b)

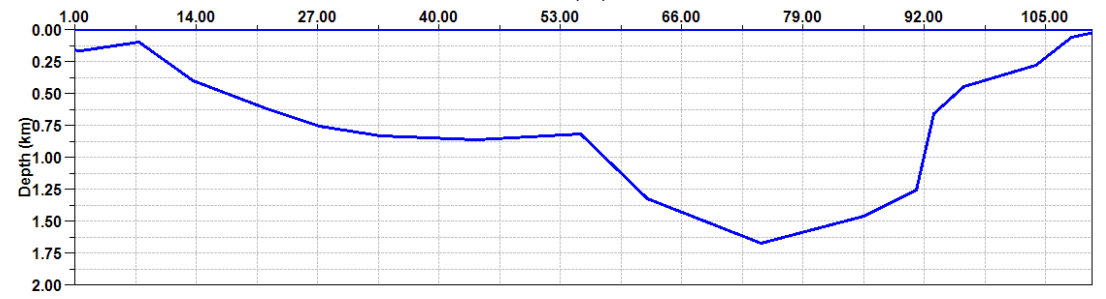

Figure 8 - Profile $A A^{\prime}$. (a) Red dots indicate the observed anomaly and the blue line indicates the fitted anomaly. (b) Blue line indicates the modeled basement relief.

(a)

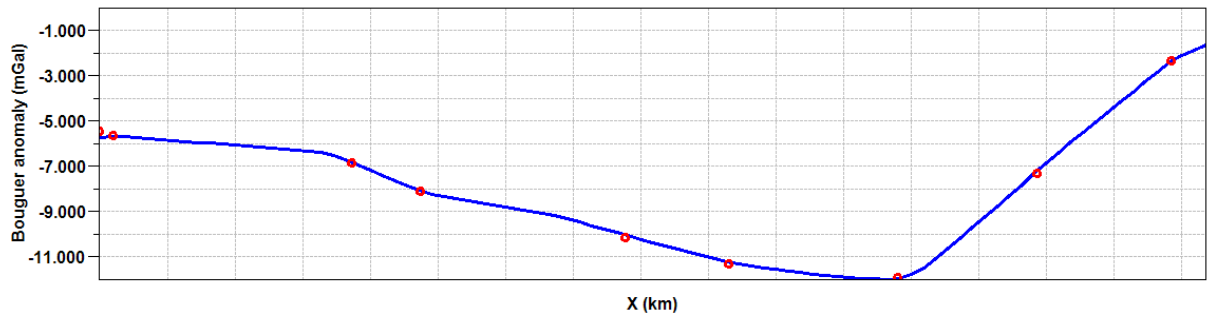

(b)

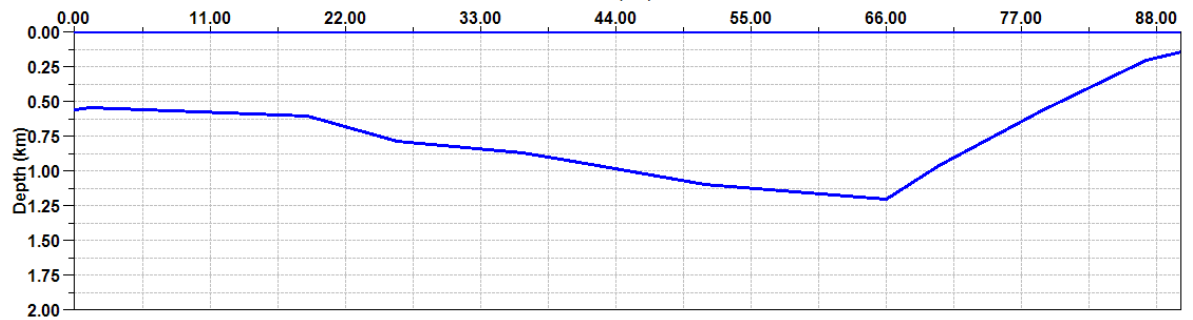

Figure 9 - Profile BB'. (a) Red dots indicate the observed anomaly and the blue line indicates the fitted anomaly. (b) Blue line indicates the modeled basement relief.

(a)

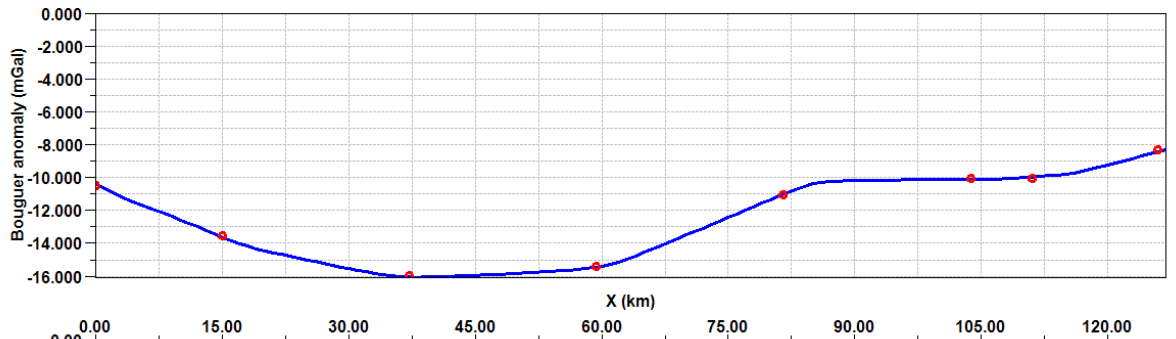

(b)

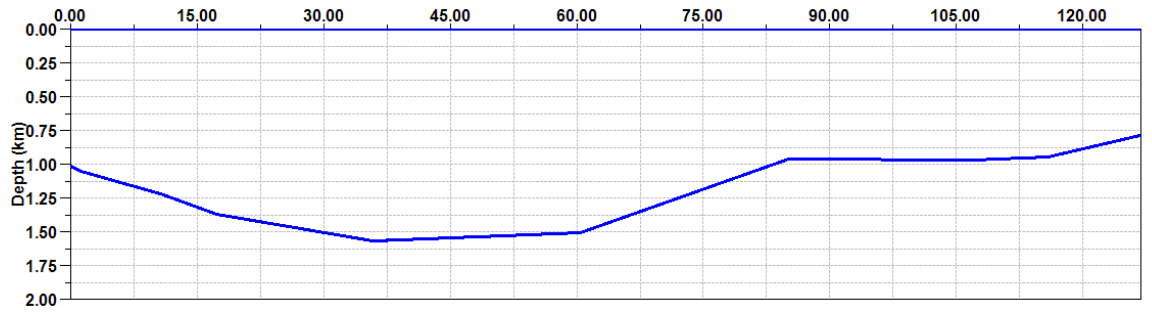

Figure 10 - Profile CC'. (a) Red dots indicate the observed anomaly and the blue line indicates the fitted anomaly. (b) Blue line indicates the modeled basement relief. 
(a)

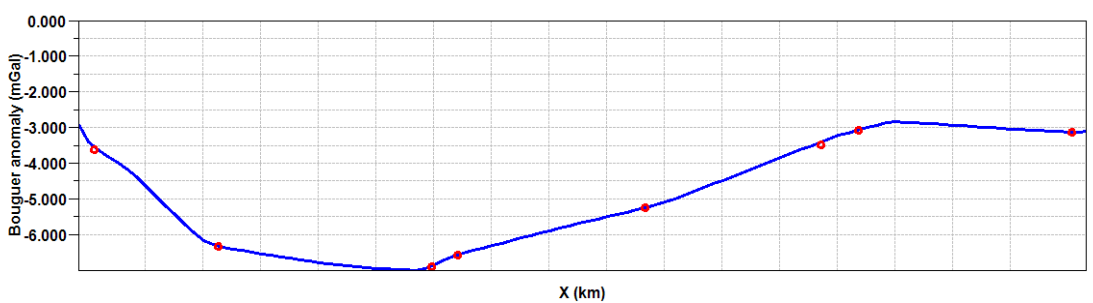

(b)

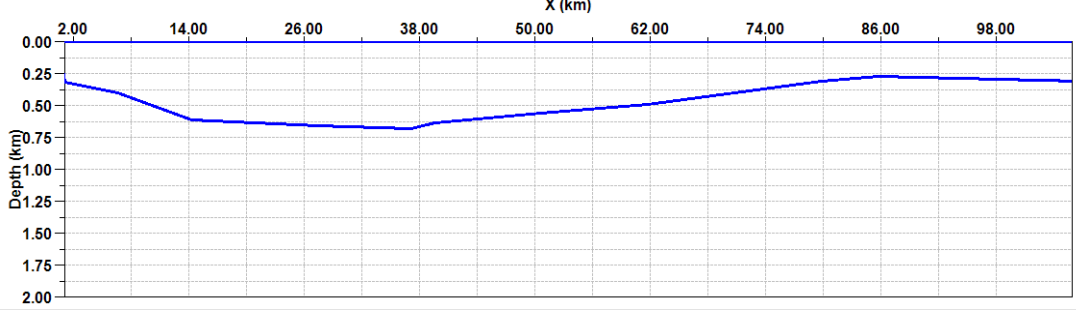

Figure 11 - Profile DD'. (a) Red dots indicate the observed anomaly and the blue line indicates the fitted anomaly. (b) Blue line indicates the modeled basement relief.

(a)

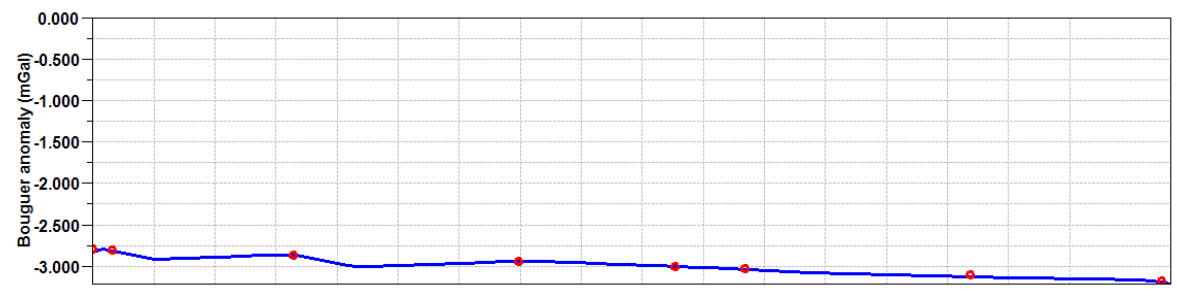

(b)

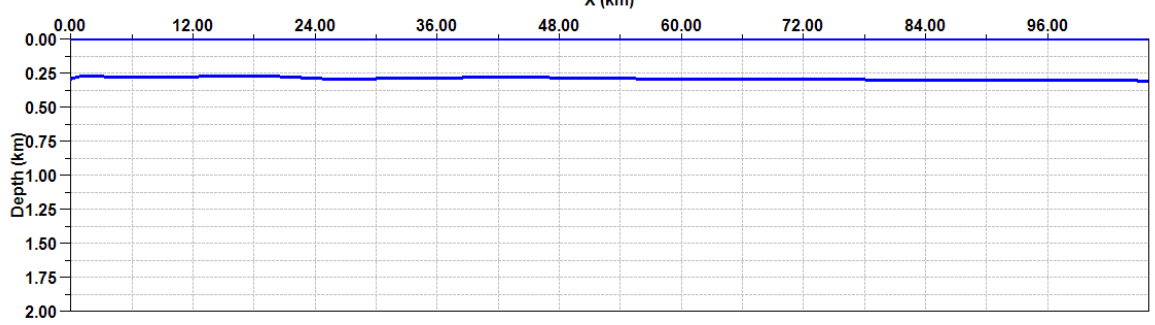

Figure 12 - Profile EE'. (a) Red dots indicate the observed anomaly and the blue line indicates the fitted anomaly. (b) Blue line indicates the modeled basement relief.

(a)

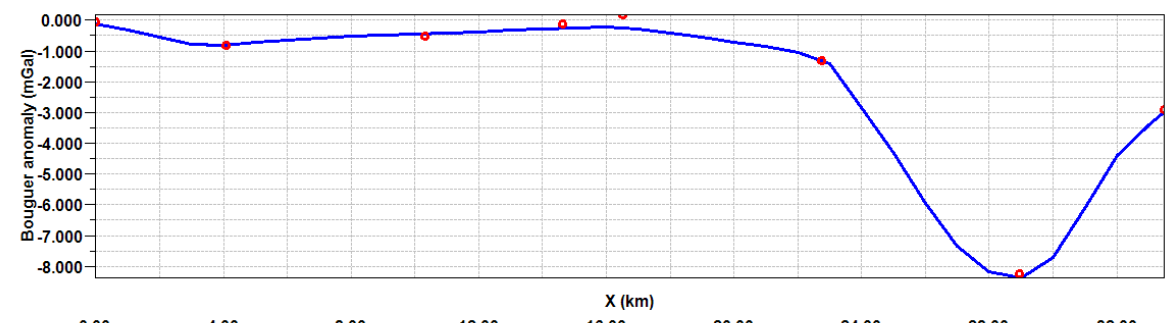

(b)

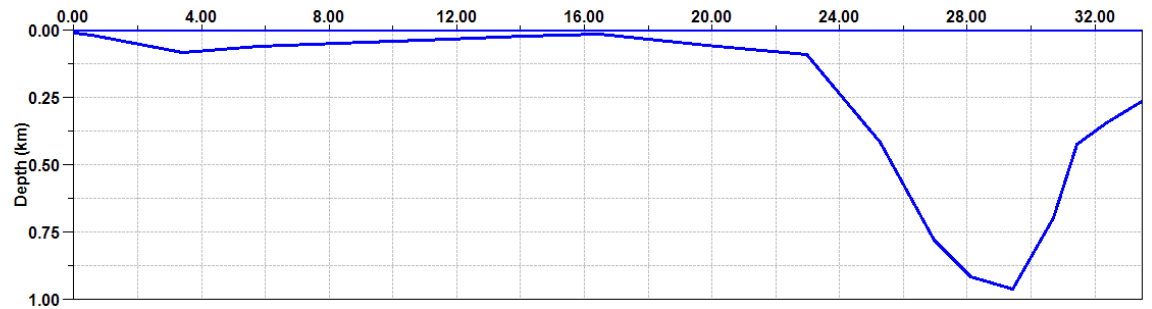

Figure 13 - Profile FF'. (a) Red dots indicate the observed anomaly and the blue line indicates the fitted anomaly. (b) Blue line indicates the modeled basement relief. 